\title{
Idiom i imię Boga
}

\author{
Urszula Idziak-Smoczyńska (iD) https://orcid.org/0000-0002-3469-5264 \\ Instytut Religioznawstwa \\ Uniwersytet Jagielloński \\ e-mail: urszula.idziak-smoczynska@uj.edu.pl
}

\section{Abstract \\ Idiom and the Name of God}

In this article the author follows Derrida's deconstruction of the Babel tower parable, showing how God's name is structured by difference, instead of identity. The story of the tower of Babel introduces not only the origin of languages and the necessity of translation, but the ultimate untranslatable - the name. God's name, hence every name becomes for Derrida another quasi-transcendental, which conditions of possibility (identity) are concurrently conditions of impossibility (difference).

Keywords: name, idiom, Derrida, deconstruction, antagonistic theology, Babel

Słowa kluczowe: imię, idiom, Derrida, dekonstrukcja, Babel, teologia antagonistyczna

„Wszystkie litery tworzą kształt nieobecności. Tak zatem Bóg jest dzieckiem Swojego Imienia. Rabi Tal"

Edmond Jabès

W tradycji filozofii religii istnieją dwa główne nurty, które traktują imię Boga jako punkt odniesienia do wszelkiego namysłu nad językiem: pozytywny i negatywny. Ten pierwszy polega na wpisaniu imienia Boga w tradycję Parmenidesowej ontologicznej zasady tożsamości, imieniem Boga jest Summum Ens, pisane wielkimi literami. Ten drugi pojawia się wówczas, gdy, począwszy od Anzelma, imię Boga jest przekroczeniem wszelkiej wiedzy o Bogu, transcendencją epistemologiczną, od której zaczyna się teologia negatywna. Imię Boga oznacza przekroczenie wszelkiego predykatu albo zaprzeczenie wszelkim redukcyjnym opisom. Wielu autorów dwudziestowiecznej filozofii religii szukało połączenia między negatywnością filozofii ponowoczesnej a apofatyczną odmianą teologii. Jednak w drugiej połowie XX wieku 
wyłoniła się trzecia linia, którą określiłabym jako „antagonistyczną” albo nazwała linią niezgodności lub niezgody. W tej perspektywie imię Boga równa się wypowiedzeniu wojny ${ }^{1}$.

Zanim przedstawię myśl Derridiańską, której niewątpliwie najbliżej do tego tertio, trzeba wspomnieć filozofów, którzy tę trzecią drogę zainicjowali, a więc przede wszystkim Friedricha Nietzschego ${ }^{2}$. Odnajdujemy u niego antagonizm właśnie po stronie boskości, destrukcję brzemienną przyszłością, dionizyjską radość destrukcji. I chociaż chrześcijański Bóg jest przez Nietzschego postawiony w opozycji do tej formy afirmującej regeneracji, to jednak, jak zauważano wielokrotnie, nie stoi od niej aż tak daleko ${ }^{3}$. Lektura Nietzschego, która wychodzi ponad szukanie różnic z chrześcijaństwem, musi uwzględnić specyfikę jego rozumienia mistycyzmu. Etymologia wskazuje zbieżność mistycyzmu z misteriami greckimi (gr. mystikos znaczy „tajemny”), co oddala mistycyzm od wiedzy o Bogu, a przybliża ku doświadczeniu“. To pierwsze pojęcie określane jest jako „teologia mistyczna”, poszerzająca wiedzę o Bogu, a drugie jako sam „mistycyzm” - rzeczownik, który według Michela de Certeau jest pojęciem nowoczesnym (wcześniej występował wyłącznie przymiotnik „mistyczny”5) i ogranicza się do doświadczenia. Do tego dualizmu należy dodać wymieniony już podział na negatywność i pozytywność. Istnieje apofatyczny mistycyzm, związany z Dionizym Areopagitą, oraz pozytywny mistycyzm zjednoczenia z Bogiem. Te dwa podziały, epistemiczny i eksperymentalny oraz pozytywny i negatywny przecinają się na wiele sposobów. Wyrazem negatywności może być rozpoznanie faktu, iż Bóg jest tym, co ukryte przed doświadczeniem. Byłby to wówczas mistycyzm apofatyczności doświadczenia. Przeważnie jednak teologia mistyczna przenika się z teologią negatywną, co inspiruje różne formy myśli ponowoczesnej, jak choćby mistycyzm ateistyczny Georges'a Bataille'a. Należy zwrócić uwagę na kontekst, w którym określamy coś mistycyzmem ${ }^{6}$. Podstawową kwestią są rozważania nad sensem porównań międzykulturowych oraz anachroniczność tego typu analiz, ale być może na tym skrzyżowaniu wiedzy i doświadczenia, pozytywności i negatywności ważniejsze jest pytanie o język. Michel de Certeau przecina to skrzyżowanie, mówiąc wprost: mistycyzm jest dyskursem, „sposobem mówienia” . Jest zatem mistycyzm językiem, ale językiem bardzo specyficznie rozumianym. Nie jest aktem mowy ani formą wyrazu, lecz raczej aktem woli, ,volo", bliskim performatywności ${ }^{8}$, chociaż dość negatywnej (jak zauważa Hent de Vries) ${ }^{9}$. Wreszcie, de Certeau

${ }^{1}$ Bliska tej trzeciej drodze jest postmodernistyczna ,ateologia” Marka C. Taylora, Erring. A Postmodern A/theology, Chicago-London 1984.

${ }^{2}$ F. Nietzsche, Radosna wiedza, tłum. M. Łukasiewicz, Gdańsk 2008.

3 T.T. Roberts, Contesting Spirit. Nietzsche, Affirmation, Religion, Princeton 1998, s. 22.

${ }^{4}$ Por. W. Burkert, Ancient Mystery Cults, Cambridge, Mass. 1987; T.T. Roberts, Contesting..., op. cit., s. 112.

${ }^{5}$ M. de Certeau, La fable mystique. XVIe-XVIIe siècle, Paris 1982, s. 76.

${ }^{6}$ Por. S. Katz, Mysticism and Language, Oxford 1992; M. de Certeau, La fable..., op. cit.

${ }^{7}$ M. de Certeau, La fable..., op. cit., s. 104, 157.

8 Ibidem, s. 167, przyp. 26.

${ }^{9}$ H. de Vries, Anti-Babel. The „Mystical Postulate” in Benjamin, de Certeau and Derrida, „MLN” 1992, vol. 107, no. 3, s. 446. 
stwierdza, że mistycyzm to anty-Babel - szukanie nie nowego języka, lecz nowego doświadczenia języka po tym, jak ludzki język został rozproszony i pomieszany ${ }^{10}$.

Mimo że Jacques Derrida był wielokrotnie wiązany z teologią negatywną, to pytany wprost, odżegnywał się od niej w takim samym stopniu jak od pozytywnego mistycyzmu, zostawiając jedynie otwartą furtkę dla możliwych porównań swojej filozofii i definicji mistyczności do myśli de Certeau. Jednak nigdy owej definicji nie podał wprost $^{11}$.

\section{Babel jako dekonstrukcja, czyli Bóg, który staje po stronie różnicy}

Wspomniana wcześniej koncepcja anty-Babel sugeruje, że to właśnie w tym miejscu, opisanym w Księdze Rodzaju, szukać należy korzeni doświadczenia języka. Będzie to doświadczenie języka (a nie język jako narzędzie zdobywania wiedzy o Bogu), które nie jest pozytywne, ale też niekoniecznie musi być negatywne. Niewątpliwie ma ono niewiele wspólnego z wielością i pomieszaniem, ale niekoniecznie musi być rozumiane jako powrót do utraconej jedności.

Jednym z wyjaśnień Derridy dotyczących jego rozumienia „dekonstrukcji” było wyrażenie ,plus d'une langue" ${ }^{2}$. Ma ono dwa możliwe odczytania, w zależności od tego, w jaki sposób przeczytamy je na głos. Gdy wymawiamy końcowe „s” w plus, znaczy „więcej”, a więc więcej niż jeden język. Kiedy „," pozostaje nieme, wyrażenie znaczy „nigdy więcej jednego języka”. Ta najkrótsza definicja „dekonstrukcji”, cierpiąca na głęboką, sięgającą aż fonetyki dwuznaczność prowadzi nas do źródła wielości języków, w którym jedno plus odnosi się do utraconej mowy pierwotnej, a drugie do rodzącej się z tego wielości, czyli właśnie Babel. Zatrzymanie się przy analizach tego fragmentu Księgi Rodzaju (Rdz 11,1-9), do których Derrida wraca wielokrotnie $^{13}$, wydaje się więc niezbędne, aby zrozumieć istotę dekonstrukcji.

Historia Babel jest powszechnie interpretowana jako zawierająca w sobie tajemnicę języka ${ }^{14}$. Tradycyjnie przypisuje się w tej przypowieści Bogu jedność, zaś światu upadłemu wielość, którą symbolizuje kara pomieszania języków. Jednak, jak dostrzega Derrida, zbyt wiele elementów tym przekonaniom przeczy: po pierwsze, świątynia w kształcie wieży wyznacza swym kierunkiem wznoszenie się ku jedności - hebrajski Bóg nie występuje tu przeciw obcym wyznaniom, ale przeciw jedności, dla której „nic nie będzie niemożliwe” (Rdz 11,6) ${ }^{15}$. Bóg staje zatem wyraźnie po stronie różnicy. Po drugie, w wersie 9 kolejność stylistyczna uniemożliwia

${ }_{10}$ Ibidem, s. 445, M. de Certeau, Heterologies, thum. B. Massumi, Minneapolis-London 1986, s. 88.

${ }^{11}$ Altérités, F. Guibal (red.), Paris 1986, s. 32. O teologii negatywnej, zob.: Derrida and Negative Theology, H. Coward, T. Foshay (red.), New York 1985.

12 J. Derrida, Mémoires pour Paul de Man, Paris 1988.

13 J. Derrida, Psyché. Inventions de l'autre, Paris 1987, s. 203-211; idem, Ulysse gramophone - deux mots pour Joyce, Paris 1987; idem, L'oreille de l'autre, Paris 1982, s. 98-104.

${ }_{14}$ P.M. Sherman, Babel's Tower Translated. Genesis 11 and Ancient Jewish Interpretation, LeidenBoston 2013, s. 1, przyp. 3.

${ }^{15}$ Wszystkie przekłady z Biblii (jeżeli nie podano inaczej) za: Pismo Święte Starego i Nowego Testamentu, oprac. Zespół Biblistów Polskich z inicjatywy Benedyktynów Tynieckich, Poznań 1998. 
interpretowanie różnic językowych jako będących konsekwencją rozproszenia. Jedno poprzedza drugie: „tam bowiem Pan pomieszał mowę mieszkańców całej ziemi. Stamtąd też Pan rozproszył ich po całej powierzchni ziemi" $(\operatorname{Rdz} 11,9)^{16}$. Po trzecie, Bóg interweniując i zaprowadzając taką karę, objawia w nazwie miasta zarówno siebie, jak i pomieszanie (hebr. bālal znaczy mieszać, pomieszać) ${ }^{17}$, czym sprawia, że jego kara jest rozporządzeniem semantycznie zgodnym z nim samym.

Zamiast imienia chroniącego przed rozproszeniem pojawia się zatem imię oznaczajace „rozproszenie”, w dodatku jest to imię, które rozpoczyna problem transla$\mathrm{cjj}^{18}$. Derrida zwraca uwagę na to, że w istocie wszelkie imię sprawia, że translacja staje się problemem. Problem przekładu rodzi się nie tylko wraz z wielością języków, ale przede wszystkim razem z nieprzekładalnością imienia własnego.

Druga kwestia łącząca się z imieniem własnym to ciąg genealogiczny, który przerywa biblijną opowieść o wieży Babel. Historia ta jest umieszczona między dwoma genealogiami synów Noego, ewidentnie burząc płynne przejście między nimi. Od pierwszego wersu dziesiątego rozdziału Księgi Rodzaju rozpoczyna się spis potomków Noego, który kończy się słowami „oto szczepy synów Noego według ich pokrewieństwa i według narodów. Od nich to wywodzą się ludy na ziemi po potopie" (Rdz 10,32). Wówczas następują rozdział jedenasty opowiadający o Babel oraz rozdział dwunasty, który wraca do genealogii. Zaskakujące jest to, że po raz drugi podani są w nim potomkowie Sema; w rozdziale dziesiątym wymienieni są: Elam, Aszszur, Arpachszad, Lud i Aram (Rdz 10,21), w jedenastym pozostaje tylko Arpachszad i wyprowadzone są od niego kolejne pokolenia aż do Abra(ha)ma. Brzmi to tak: „Gdy Sem miał sto lat, urodził mu się syn Arpachszad, w dwa lata po potopie. Po urodzeniu się Arpachszada Sem żył pięćset lat i miał synów i córki. Arpachszad, przeżywszy trzydzieści pięć lat, miał syna Szelacha. A po urodzeniu się Szelacha Arpachszad żył czterysta trzy lata i miał synów i córki” (Rdz 11,10-14). Cały ten rozdział, w odróżnieniu od dziesiątego powtarza tę strukturę, wymieniając wiek ojca w roku narodzin syna oraz dalszą długość jego życia po narodzinach potomka. Derrida nie mógł nie dostrzec tego związku między językiem a filiacją. Pisał: „,[Bóg] podejmuje dekonstrukcję języka uniwersalnego, rozprasza pokrewieństwa genealogiczne [filiation], przerywa następstwo pokoleń [lignée]" ${ }^{19}$. W istocie opowieść o Babel rażąco rozdziela dzieje tej rodziny, przerywając monotonny rytm wymiany kolejnych imion zmianą konwencji. W rozdziale dziesiątym znajduje się jeszcze jedna zaskakująca uwaga, wielokrotnie powtórzona: „oto synowie [Sema] podzieleni według swych krajów i swego języka, według szczepów”, co sugeruje że podział języków ${ }^{20}$ według

16 Por. Ps 55,10-12, gdzie pojawia się ten sam motyw pomieszania języków i rozproszenia ludzkości.

${ }^{17}$ J. Derrida, L'oreille..., op. cit., s. 138. Derrida cytuje z pamięci thumaczenie André Chouraquiego i twierdzi, że pojawia się tam thumaczenie „Bavel, Confusion” wielką literą. Tego jednak nie ma w wydaniu Chouraquiego przez Desclée Brouwer za: https://www.idixa.net/Pixa/pagixa-1909140944.html [dostęp: 28.06.2020]. W kwestii thumaczenia zob.: P.M. Sherman, Babel's Tower..., op. cit.

${ }_{18}$ Por. J. Day, From Creation to Babel, Studies in Genesis 1-11, London 2013.

19 J. Derrida, Psyché, op. cit., s. 207. W obrębie cytatów wszystkie wtrącenia oraz odniesienia do słów w językach oryginału pochodzą od autorki, chyba, że zaznaczono inaczej.

${ }^{20}$ „Język” w Rdz 10 to šafah/sāpâ, czyli „usta” (w liczbie pojedynczej). Natomiast w Rdz 11 język to już lason, czyli język jako narząd jamy ustnej. Chouraqui zachowuje to dosłowne znaczenie i tłumaczy 
porządku Pisma nastąpił przed Babel. Pojawia się tam również zdanie, które według komentarzy jest odniesieniem do epizodu wieży Babel: „Eberowi urodzili się dwaj synowie; imię jednego Peleg, gdyż za jego czasów ludzkość się podzieliła, imię zaś jego brata - Joktan" (Rdz 10,25). To, że przywołany jest tu etymologiczny korzeń imienia Peleg, czyli hebr. palag - „dzielić”, świadczy o tym, że podział jest czymś innym niż tylko pomieszaniem. Babel pojawia się, dzieląc opis potomków Sema: po tej opowieści, która mówi o jednym imieniu, używając pojęcia sem, tekst wraca do synów Sema i z jednego spośród nich wyprowadzamy genealogię semitów. Imię najstarszego syna Noego oraz imię (już nie jako nazwa własna, ale uniwersalna), pod wezwaniem którego zbierają się budowniczy wieży, jest homonimiczne, dlatego wers: „i w ten sposób zdobędziemy sobie imię” należałoby rozumieć jako nawiązanie do występującego przed opowieścią o Babel i po niej Sema, syna Noego.

\section{Dług}

Rozważaniom o Babel Derrida oddał się po raz pierwszy w 1975 roku, gdy poświęcił cykl seminariów tekstowi Waltera Benjamina pod tytułem Die Aufgabe des Übersetzers $^{21}$. Benjamin w ludzkiej zdolności nazywania dostrzega dopełnienie boskiego aktu stwórczego ${ }^{22}$, a w darze języka przejaw wywyższenia człowieka przez Boga. Jednak analizuje on język adamiczny, język doskonałej adekwacji, która mówiąc, jednocześnie poznaje. Tymczasem język, jaki znamy, jest owocem upadku, wielości nawzajem nieprzekładalnych i nieprzystających do rzeczywistości słów. Derrida odnajduje u Benjamina to rozumienie tłumaczenia, które nie szuka już więzi z rzeczywistością źródłową, lecz biorąc sobie do serca wydarzenie Babel, pozostaje w porządku niemożliwości. Aufgabe to zadanie, obowiązek tłumaczenia. Należy oddać to, co powinno być dane przez tekst. „Oddać”, czyli zwrócić zaciągnięty dług - od-dać znaczenie. W zadaniu tłumacza Derrida odnajduje kolejny kształt niemożliwej restytucji - daru, który pozostawia dług nieumorzonym. Odwołując się do etymologii, wskazuje w Aufgabe inne rozumienie aufgeben, które znaczy również oddać w sensie porzucić: abandonner ${ }^{23}$. Oczekiwana restytucja kończy się porzuceniem, ale też zawierzeniem (fr. s'abandonner à) językowi. U Benjamina przyjmuje ono postać postulatu dosłowności, która nie tyle opiera się na pragnieniu zachowania

lèvres (fr. confondons là leurs lèvres). Por. O. Happela, Der Turmbau von Babel, „Biblische Zeitshrift” 1903, vol. 1-2, s. 225-244. Zob. również J. Day, From Creation..., op. cit., s. 178.

${ }^{21}$ W. Benjamin., „Die Aufgabe des Übersetzers”, [w:] W. Benjamin, Gesammelte Schriften, t. 5, Frankfurt am Main 1972; idem, Zadanie thumacza, thum. J. Sikorski, [w:] idem, Anioł historii. Eseje, szkice, fragmenty, wybór i oprac. H. Orłowski, tłum. K. Krzemieniowa, H. Orłowski, J. Sikorski, Poznań 1996, s. 89-103.

${ }^{22}$ W. Benjamin pisał: „Bóg nie stworzył człowieka ze słowa i nie nazwał go. Nie chciał go poddawać językowi. Zamiast tego w człowieku uwolnił język, który jemu posłużył za medium stworzenia. Bóg odpoczął, gdy w człowieku pozostawił swą stwórczą moc samej sobie"; W. Benjamin, O języku w ogóle i języku człowieka, tłum. A. Lipszyc, „Literatura na Świecie” 2011, nr 5-6, s. 7-26.

${ }_{23}$ J. Derrida, Psyché, op. cit., s. 212. 
$\mathrm{sensu}^{24}$, ile przemawia przez nią „,wielka tęsknota za językowym uzupełnieniem”25. Niespłacalny dług nie dotyczy oryginału, lecz zarówno oryginał, jak i przekład cierpią na ten niedomiar w stosunku do większego, pierwotniejszego języka. Translacja skazuje na trwały i niedający się umorzyć dług wobec pierwotnego znaczenia - chociaż samo słowo „pierwotne” należałoby obłożyć odpowiednimi zastrzeżeniami.

„Babel” jako „pomieszanie” nazywa tę źródłowość. W każdym przekładzie tego fragmentu Pisma Świętego zachowane jest hebrajskie słowo „Babel”. Tłumaczenie pozostaje więc zadaniem niewykonalnym ${ }^{26}$. Tej samej regule poddaje się wszelki wtrącony w jednolity tekst obcy idiom albo cytat pozostawiony w obcym języku (np. fragment Stéphane'a Mallarmégo w eseju Benjamina). Pełni on rolę imienia własnego - znaczącego, a jednak nieprzekładalnego. Czyste wydarzenie „siły performatywnej”27, które nawet doskonały przekład zagubi. Nie da się oddać tego, co zostało dane w języku źródłowym - czy zatem w tłumaczeniu chodzi o sens? Sens jest wprawdzie przekładalny, ale celem tłumaczenia nie jest komunikowanie go „nie jest ani obrazem, ani kopią”, „ani recepcją... ani przedstawieniem”28. Tłumaczenie nie jest mechanizmem, który zawodzi w przypadku tekstów świętych i poezji, wręcz przeciwnie, im właśnie, jako z istoty niemożliwe do zrealizowania, przynależy. Nie należy więc szukać wspólnej płaszczyzny przekładu. Nie mamy apriorycznej możliwości przekładu jednego języka na drugi, nie istnieje doskonały dwujęzyczny słownik. Na samym początku mamy jedynie żądanie. Dzieło „wymaga przekładu, nawet gdy nie ma żadnego tłumacza mogącego odpowiedzieć na ten nakaz, który jest jednocześnie prośbą i pragnieniem obecnym w samej strukturze oryginału"29.

Dług jest zatem obosieczny. Leży w równym stopniu po stronie oryginału, co po stronie wersji, ponieważ oryginał domaga się przekładu. Dług jest po stronie Boga, gdy pozostawia w miejscu Babel pomieszane mowy i swoje imię, ,które musi być tłumaczone jako pomieszanie", żeby stać się zrozumiałym, a więc, po to, by pozwolić zrozumieć, że jest ono trudne do przełożenia, i do rozumienia" ${ }^{\prime 30}$. Oto aspekt antagonistyczny wydarzenia Babel. Bóg mieszając języki, sam miesza się, a więc zniża się, schodzi w ludzkość ze swoim imieniem. Nie pozwalając, aby ludzie zuniwersalizowali własną mowę, musi poddać się swojej karze, pozostawiając „Babel” - a więc swoje imię - nieprzetłumaczalnym. Derrida powie: „Bóg opłakuje swoje imię” ${ }^{11}$. Wówczas teologia negatywna, odsuwająca kolejne imiona boże, nie dość doskonałe, by uchwycić boską istotę, musiałaby zostać zastąpiona zaproponowaną we wstępie

${ }^{24}$ W. Benjamin, Zadanie thumacza, thum. A. Lipszyc, „Literatura na Świecie” 2011, nr 5-6, s. 27-41; „Samo przez się rozumie się wreszcie, jak bardzo wierność w oddawaniu formy utrudnia oddanie sensu. Stąd też postulatu dosłowności nie sposób wywieść z pragnienia, by zachować sens".

${ }^{25}$ Ibidem, s. 30.

${ }^{26}$ Ibidem.

27 J. Derrida, Psyché, op. cit., s. 213.

${ }^{28}$ W. Benjamin, Anioł historii, op. cit., s. 89: ,istotą jego [ttumaczenia] nie jest komunikat, nie jest wypowiedź" (tłum. własne).

${ }^{29}$ J. Derrida, Psyché, op. cit., s. 216.

${ }^{30}$ Ibidem, s. 218.

${ }^{31}$ Ibidem, s. 219. Por. J. Derrida, Edmond Jabès i pytania księgi, thum. A. Wodnicki, „Literatura na Świecie" 2001, nr 7, s. 137-159. 
teologią , „antagonistyczną”, która mnoży przez różnicowanie i stale domaga się niemożliwego przekładu.

Struktura, zarówno u Benjamina, jak i Derridy, ma charakter teleologiczny. Nie ma pierwotnej jedności, jest kontraktem skierowanym ku przyszłości. Babel nie jest opowieścią o genealogii języków, ale o przyszłości. „Tłumaczenie czyni obecnym (fr. rend présente) jedynie na sposób antycypacyjny, zwiastujący, quasi-profetyczny pokrewieństwo, które nigdy nie jest obecne w tym uobecnieniu" ${ }^{32}$. Dlatego źródłowym elementem, z którego tłumacz składa swój tekst, nie jest wyrażenie, lecz słowo. Według Benjamina zachowuje ono prześwit, przez który widzieć możemy oryginał. Jednak nie chodzi tu o adequatio rei et intelectus ani adequatio między jednym językiem a drugim. Jak zauważa Derrida, jesteśmy tu nie w porządku metonimii, ale symbolu (rozumianego przez pryzmat etymologii), a więc nie wzajemnego odzwierciedlania, ale łączenia się oddzielonych części ${ }^{33}$. Derrida pisze: „Jeżeli to, co źródłowe domaga się dopełnienia, oznacza to, że u źródła nie było bez winy, pełne, kompletne, totalne, tożsame samo ze sobą" ${ }^{34}$ i cytuje Benjamina: „Zadaniem thumacza jest ów czysty język, który przebywa na wygnaniu w obcych językach, wybawiać we własnym, język uwięziony w dziele, uwalniać w trawestacji”35. Ten „czysty język” nie jest utraconą pierwotnością, ale czystością mającą się z wielości narodzić. Niemożliwe dążenie do nieskalanego przekładu budzi skojarzenie z pragnieniem, które dążąc do czystości, jednocześnie czystość kala. Tym dziewiczym przekazem nie jest sens, ale coś, co po pracy translatorskiej musi zrodzić się na nowo, nietknięte. To, co zostaje naruszone w mariażu dwóch języków, odradza się czyste w postaci nowego stworzenia-przekładu.

„Tłumaczenie obiecuje królestwo pogodzenia się języków”36. Benjamin dopatruje się tego królestwa w nakładaniu się wielu językowych intencji. Te intencje nie dotyczą więc niczego pozajęzykowego, ale języka czystego (niem. die reine Spra$\left.c h e^{37}\right)$, „nie język uniwersalny w rozumieniu Leibniza”, ale „bycie językiem języka” (fr. l'être-langue de la langue ${ }^{38}$ ). Mowa więc o wzajemnym dopełnianiu, które nigdy nie dochodzi do pełni, o intencjonalności, która nigdy nie zyskuje zaspokojenia, nie z powodu jakiejkolwiek słabości, ale dlatego, że zarówno dopełnianie, jak i intencjonalność ostatecznie wskazują na wielość języków. Derrida pisze, kładąc nacisk na liczbę mnogą: ,jedność bez żadnej tożsamości ze sobą, która sprawia, że są języki (fr. qu'il y a des langues), i że są to języki" "39.

32 J. Derrida, Psyché, op. cit., s. 220.

${ }_{33}$ W. Benjamin, Aniot historii, op. cit., s. 99: ,[...] tak jak skorupy jakiegoś naczynia, aby dały się złożyć, muszą się ze sobą zgadzać co do najdrobniejszych szczegółów, a mimo to nie równać, tak przekład zamiast upodabniać się do sensu oryginału, musi w swoim języku pieczołowicie i co do najdrobniejszego szczegółu przyswoić sobie jego sposób myślenia, aby obydwie te skorupy dały się rozpoznać jako fragment bogatszego języka".

${ }^{34}$ J. Derrida, Psyché, op. cit., s. 222.

35 W. Benjamin, Zadanie thumacza, op. cit.

${ }^{36}$ J. Derrida, Psyché, op. cit., s. 231.

37 W. Benjamin, Anioł historii, op. cit., s. 97: ,prawdziwy”. W przekładzie A. Lipszyca: „,czysty”.

${ }^{38}$ J. Derrida, Psyché, op. cit., s. 232.

${ }^{39}$ Ibidem. 
Derrida, relacjonując translatorskie rozważania Benjamina, zwraca uwagę na religijny język, ponieważ to sakralna literatura będzie modelem i odniesieniem wszelkiego przekładu. Tłumaczenie jako „święte wzrastanie języków” nie wskazuje jedności jako ideału u kresu tego postępowania, lecz uznaje za ideał sam dystans. Sakralny tekst wzywa nas do tłumaczenia, a ponieważ jest to zadanie niewykonalne, poddaje ono człowieka nieskończonemu poczuciu winy, które jednocześnie z winy usprawiedliwia. Święty tekst „,spełnia prawo, o którym mówi i od przepaści do przepaści dekonstruuje wieżę, każdą wieżę, wszelkie rodzaje wież" ${ }^{40}$. Wypowiadając słowo „Babel”, nie wiemy, do jakiego języka przynależymy, nie wiemy, czego znakiem jest wielka litera, której używamy (nazwy własnej czy majestatu Boga?). Nie wiemy, czy, jak André Chouraqui, powinniśmy, przekładając to pojęcie z hebrajskiego, użyć wielkiej czy małej litery, pisząc Confusion (Pomieszanie). Tłumaczenie, które nie mówi o sensie, lecz wskazuje sposób ukazania się sensu, powierza się sakralności tekstu. Nie odsuwa się od niego, przyjmując objawiony sens, ponieważ nie ma sensu poza jego obszarem. Tekst sakralny jest „tekstem absolutnym”, ponieważ nie jest ważna jego treść, lecz samo jego wydarzenie. Żaden sens nie daje się z niego wy-prowadzić. Dlatego to powierzenie jest wzajemne - jedno oddaje się drugiemu, powtarzając niejako boskie prawo spod zburzonej wieży Babel: obowiązku i zakazu przekładu.

\section{Przeżycie}

Wydaje się, że mamy tu do czynienia z ograniczeniem, tymczasem z perspektywy Derridy i jego koncepcji literatury jest to uwolnienie literalności, dzięki któremu literatura, „która stara się odkupić zagubioną sakralność”, odzyskuje życie litery, niebędącej już martwym nosicielem znaczenia. To życie również dopiero ma być. Przekład nie jest utrzymywaniem „przy życiu” autora, przedłużaniem życia jego dzieł. „Dzieło nie żyje jedynie dłużej, żyje więcej i lepiej, powyżej możliwości swojego autora" ${ }^{41}$. Nie przedłuża życia samego autora, najwyżej trwałość jego podpisu (a należy tu przyjąć szczególne Derridiańskie rozumienie sygnatury, którą będziemy analizowali $\mathrm{w}$ dalszej części rozważań). Benjamin związek przekładu z oryginałem określił mianem „związku życia”: „Tak jak wyrazy życia pozostają w najściślejszym związku z tym, co żyje, choć nic dla niego nie znaczą, tak też przekład wypływa z oryginału. Wprawdzie nie tyle z jego «życia», co raczej z jego «przeżycia» [Überleben]”42. Derrida pisze: „Tekst żyje jedynie, jeżeli prze-żywa, a prze-żywa jedynie jeżeli jest zarazem możliwy do tumaczenia [traductible] i nieprzetłumaczalny [intraduisible] [...]. Zwyciężając, tłumaczenie nie jest ani życiem, ani śmiercią tekstu, jedynie, albo już jest jego przeżyciem. Powiemy to samo o tym, co nazywam pismem, znakiem, śladem itd., nie żyje to, ani nie umiera, lecz przeżywa.

${ }^{40}$ Ibidem.

${ }^{41}$ Ibidem, s. 214.

${ }^{42}$ W. Benjamin, Zadanie ttumacza, thum. A. Lipszyc, op. cit. s. 29. W tomie Aniot historii w przekładzie J. Sikorskiego Überleben przetłumaczone jest jako ,przetrwanie”, gubi więc istotny sens, op. cit., s. 91. 
I «rozpoczyna» się jedynie przeżyciem (testamentem, iterowalnością ${ }^{43}$ [itérabilité], pozostawaniem [restance $]. . . "{ }^{44}$. Religijne podejście Benjamina do języka ma tę samą strukturę, co ateistyczne podejście Derridy ${ }^{45}$. Chodzi jedynie o odwrócenie, w którym (znów posługując się przykładem Benjamina) niezapomniane przeżycie nie jest niezapomnianym ze względu na możliwości ludzkiej pamięci ${ }^{46}$, lecz jego niezapominalność jest aprioryczna i faktyczne zapomnienie w niczym jej nie dotyczy. Życie tekstu również nie ma nic wspólnego z zawsze istniejącą groźbą, że praca tłumacza mu je odbierze. Nawet jeżeli grozi mu śmierć w przekładzie, nie zmienia to w niczym jego życia żądającego translacji. Dług nie obowiązuje w stosunku do autora. Jest długiem jako prze-dłużeniem (fr. survie - „przeżyciem”) samego życia. Żywy tekst nie może oczekiwać od tłumacza wiernej kopii, lecz oddając się mu, „przeżywa w przemianie" ${ }^{47}$. Tekst odrywa się od autora i zaczyna życie na własny rachunek, mnożąc interpretacje i znaczenia. Tekst tworzy inne teksty, komentarze, plagiaty, przekłady, interpretacje złe i dobre itd.

\section{Wojna}

Bóg przerywa zatem dążenie do jedności imienia, a swoim zejściem i swoim imieniem zaprowadza pomiędzy ludźmi nieporozumienie. Przeciwstawiając się jedności potomków Sema, schodzi jako wojna. Derrida przypomina zdanie z Finnegans Wake Jamesa Joyce'a: „Czyż Babel i Lebab nie będą razem? A tak byłon”48 („And shall not Babel be with Lebab? And he war" ${ }^{49}$ ). Wbrew polskiemu przekładowi, który zwrotem „byłon” oddaje „war” jako niemiecki czasownik być w czasie przeszłym, Derrida dostrzega, że po odwróconym Babel (Lebab) przywołane jest imię Boga w sformułowaniu ,he war”, gdzie słowo „war" przetłumaczone jest dosłownie jako wojna.

43 Iterowalność („Iterowalność”, tłum. M.P. Markowski; „Iteratywności”, tłum. P. Mrówczyński, [w:] Religia. Seminarium na Capri prowadzone przez Jacquesa Derridę i Gianniego Vattimo, w którym udziat wzięli Maurizio Ferraris, Hans-Georg Gadamer, Aldo Gargani, Eugenio Trias $i$ Vincenzo Vitiello, tłum. M. Kowalska i in, Warszawa 1999, s. 13) jest pojęciem, które wskazuje, że pojedynczość dzieła zawsze musi być powtórzona, aby stała się czytelna. Por. J. Derrida, Marginesy filozofii, tłum. A. Dziadek, J. Margański, P. Pieniążek, Warszawa 2002, s. 385: „Iterowalność (Iter pochodzi od itara, co w sanskrycie znaczy «inny», i wszystko, co następuje, można odczytywać jako wyzyskiwanie logiki łączącej powtórzenie z innością) określa cechę samego pisma, i to bez względu na jego rodzaj”.

44 J. Derrida, „Journal de bord”, [w:] Parages, Paris 1986, s. 147-149.

45 O różnicach pomiędzy Benjaminowskim, Derridiańskim i Demanowskim rozumieniem przeżycia, zob.: P. Sadzik, De Man - Derrida. Pomiędzy konieczná śmiercią a możliwym przė̇yciem, „Przegląd Filozoficzno-Literacki" 2015, nr 1, s. 139.

46 Por.: „...tak na przykład można by mówić o niezapomnianym życiu lub chwili, nawet gdyby wszyscy ludzie o nich zapomnieli. Jeśli bowiem ich istota wymaga, aby nie poszły w zapomnienie, predykat ów nie byłby fałszywy, stanowiłby jedynie żądanie, do którego ludzie się nie stosują, a być może zawierałby odsyłacz do zakresu, w którym by się sprawdził: do pamięci Boga", W. Benjamin, Anioł historii, op. cit., s. 90.

47 J. Derrida, Psyché, op. cit., s. 217.

48 J. Joyce, Finneganów Tren, tłum. K. Bartnicki, Kraków 2012, s. 258.

49 J. Joyce, Finnegans Wake, London 1939, s. 258. 
W połączeniu tych dwóch słów wręcz odczuwamy materialność tego napięcia. Jesteśmy zirytowani niejednoznaczną przynależnością wyrażenia do jakiegokolwiek języka. He sugeruje język angielski, ale domaga się w dalszych słowach czasownika. Język angielski nie zna jednak czasownika w takiej formie, a więc czytamy „war”/var/ i uznajemy je za niemiecki termin war - „,było”, jak czyni to polski tłumacz. Gdy jednak pozostajemy w obszarze języka angielskiego i czytamy war jako /wa:(r)/ i thumaczymy jako „wojna”, tracimy prawidłowość gramatyczną. Zaś w każdej z wersji pozbawiamy się możliwości przekładu pojęcia he (jako angielskiego „on”) ${ }^{50}$. Wszystkie dzieła Joyce'a nękają nas w ten sposób. W tym bełkocie (ang. babble) nie zostajemy jednak zwolnieni z wysiłku tłumaczenia. Przeciwnie, odczuwamy nakaz. Są rozpoznawane słowa i tropy, których nie sposób odsunąć. Przymierze z Bogiem u Derridy to double bind ${ }^{51}$ - dwulicowa więź albo zobowiązanie zmuszające do translacji, a zarazem ją uniemożliwiające. Derrida pisze w odniesieniu do „he war”:

Wypowiedzenie jest aktem wojennym, wypowiedział wojnę w językach, językowi i poprzez język, co dało wielość języków, oto prawda Babel, kiedy Yahwe wypowiedział jego wyraz [fr. vocable: „wyraz”, ale też „wezwanie”, w sensie „pod wezwaniem”], Babel, o którym trudno jest powiedzieć, czy była to nazwa, nazwa własna, czy zwykły rzeczownik siejący pomieszanie ${ }^{52}$.

Ewentualne przymierze z Bogiem przyjmuje postać double bind - niemożliwości tego, co zostało nakazane. „Przemień mnie - w siebie samego - a zwłaszcza nie dotykaj mnie, czytaj i nie czytaj mnie, mów i nie mów inaczej tego, co powiedziałem i co będzie [fr. aura été ${ }^{53}$ ]: w dwóch słowach co było" ${ }^{54}$ - mówi, według Derridy, Bóg-Babel, dodając nakaz noli me legere ${ }^{55}$ - nie czytaj mnie, bo czytając na głos, wejdziesz w owo zmieszanie, które nie pozwala rozstrzygnąć, jak brzmią litery (wspomnijmy owo „s” z wyrażenia plus d'une langue). A zarazem „czytaj mnie”, ponieważ jestem w tym pomieszaniu. Nie dość tego: nie „jestem”, ale „byłem”, zanim się stałem, już byłem („byłon”). Zejście Boga to już pomieszanie, to nie obecność i paruzja, ale wojna.

„He War” od samego początku rozdwaja się i „rozdwaja początek”. „Na początku różnica, oto co się wydarza, oto co już miało miejsce, $t u$, oto co było, kiedy mowa była aktem, a język pismem. Tam, gdzie to było, On był" "\$6. Zatem wewnątrz Babel, wewnątrz tego boskiego zejścia ku ludziom jest już Pomieszanie - wojna (ang. war).

${ }^{50}$ Por.: „Przeliterowuje HE WAR, i szkicuje pierwsze thumaczenie: On wojna - on wojuje, on wywołuje wojnę, robi wojnę. Można to jeszcze wymówić inaczej, trochę babelizując, ponieważ to w bardzo babelicznej scenie książki [Finneganów tren] pojawiają się te słowa, germanizując można to zatem wymówić po anglosaksońsku, HE WAR: on był”; J. Derrida, Ulysse gramophone, op. cit., s. 16.

${ }^{51}$ Wyrażenie double bind, pochodzące z języka psychiatrii, które Derrida zawsze stosuje po angielsku, znaczy „,podwójne zobowiązanie”: „la double obligation, la double demande”; Zob. J. Derrida, Parages, op. cit., s. 162; patrz też: idem, Psyché, op. cit., s. 638; idem, Glas, Paris 1974, s. 77b. M.P. Markowski używa sformułowania ,podwójne z(obo)wiązanie”, idem, Efekt inskrypcji. Jacques Derrida i literatura, Bydgoszcz 1997, s. 313.

52 J. Derrida, Ulysse gramophone, op. cit., s. 17.

53 „Aura été” - użyty jest tu czas futur antérieur (czas przyszły uprzedni).

${ }^{54}$ J. Derrida, Ulysse gramophone, op. cit., s. 40.

${ }_{55}$ Parafraza słów Chrystusa skierowanych do Marii Magdaleny: „Noli me tangere” (J 20,17).

56 J. Derrida, Ulysse gramophone, op. cit., s. 44. 
Derrida pisze: „Nie Bóg wojny, ale wojna w Bogu, wojna dla Boga, wojna $w$ imię Boga [...] Nie ma wojny bez imienia Boga i nie ma Boga bez wojny, czyli [...] bez miłości"'57.

Myśl Derridy zaczyna się przy wieży Babel, a kończy na Apokalipsie ${ }^{58}$. Tam pierwsza wojna ludu, który pragnął zbudować wieżę na chwałę swojego imienia, tu objawienie (gr. apokaluptò) jako zniesienie władzy imienia. Rozważając o kresie (nie końcu, ale zamykaniu, fr. clotûre) ${ }^{59}$, Derrida powraca w miejsce Babel, ponieważ to tam ludzkość symbolicznie zapragnęła odroczenia. Powodem gniewu Boga było ludzkie pragnienie zachowania własnego imienia przez wybudowanie wieży. Wieża była więc formą archiwizacji imienia, przekazania go, które zostało uniemożliwione przez Boga. Uniemożliwione nie przez zburzenie wieży, lecz powstrzymanie tego konsensu, wewnętrznego porozumienia, które wieżę w naszym imieniu pozwala budować. Derrida pisze: „Ani Bóg, ani synowie Sema - którzy nosili, że tak powiem, imię «imienia» (Shem) - nie wiedzieli absolutnie, że ścierali się w imię imienia, i niczego ponadto, a więc [w imię] niczego. Niczego" ${ }^{60}$. Wracając do zaproponowanej przez Derridę poprzedniej interpretacji „Pomieszania”: skoro jedna była mowa dla mieszkańców całej ziemi, musiała się pojawić jakaś inność, jeśli zapragnęli „uczynić sobie znak" (Rdz 11,4), a zatem inny był potrzebny, aby imię mogło znaczyć. Choć Derrida tego nie mówi, jasno wynika ze struktury jego tekstu, że pomieszanie języków - przekładalność znaczeń jednych na drugie - było sprowadzoną na niepokorny lud parodią imienia, które w istocie nie znaczy przecież nic. Można zatem powiedzieć, że zarówna ta pierwsza wojna, jak i ostatnia (nuklearna) są wojnami w imię samego imienia. Pierwsza poprzez imię (wyniesione w chwale) wprowadziła obcość między Boga a potomków Sema i tym samym weszła w okres odroczenia końca; druga zaś nadchodzi w epoce, która osiągnęła możliwość kresu absolutnego. Pierwsza mogła być wojną ostatnią, ale wybrała kompromis, który odroczył koniec. Kompromis zrodzony z nieświadomości tego, że była to wojna o nic, przybierał kolejne postaci „przymierza, obietnicy, religii”, czyli tego wszystkiego, co, jak mówi Derrida, „przedłuża życie, wszystkiego co trwa i trwać pozwala"61. Wydarzenie Babel ujęte jako inna wersja opowieści o grzechu pierworodnym, każe widzieć grzech, który powoduje obcość samego Boga, dotąd bliskiego. Bóg, który sam zapragnął inności, przyjmuje wybrane mu przez człowieka miejsce Innego.

Rozważania te prowadzą do próby wyłonienia nowej linii filozofii postsekularnej, a więc tej myśli, w której namysł nad językiem kierował do pisma, pisanego również wielką literą. Charakteryzuje ją pewnego rodzaju deifikacja różnicowania, pomieszania i tego, co w tej poetyce możemy określić jako babelizowanie. Dekonstrukcja

${ }^{57}$ Ibidem, s. 46.

${ }^{58}$ Dosłownie myśl Derridy kończy się na wywiadzie udzielonym Jeanowi Birnbaumowi tuż przed śmiercią pod znamiennym tytułem Je suis en guerre contre moi-même [Jestem na wojnie sam ze sobą], „Le Monde”, z 19.08.2004, https://www.lemonde.fr/archives/article/2004/08/18/jacques-derrida-je-suis-en-guerre-contre-moi-meme_375883_1819218.html [dostęp: 20.07.2020].

59 Por. J. Derrida, Fenomenologia i domknięcie się metafizyki, thum. M. Kowalska, [w:] Fenomenologia francuska. Rozpoznania, interpretacje, rozwinięcia, red. J. Migasiński, I. Lorenc, współpr. M. Kowalska, A. Leder, Warszawa 2006, s. 138-159.

${ }^{60}$ J. Derrida, Psyché, op. cit., s. 417.

${ }^{61}$ Ibidem. 
nie jest apofatyczna, nie jest też apofantyczna i deklaratywna, jest performatywna, ale perwer-formatywna, jest imperatywna, ale tym imperatywem wyrażonym w języku obcym. Oto być może język pierwotny, o który wielu pytało, stawiając również hipotezę, że może być imperatywem, a nie indicativem (m.in. Giorgio Agamben). Babel widziane przez pryzmat Benjamina i Derridy nie popada jednak w paradoks źródłowości, to znaczy nie przynależy do kultury typograficznej, która wiecznie szuka oryginału. Jest raczej reliktem kultury ustnej, w której każdy wyraz jest źródłowy, pierwszy i ostatni (por. Werner Kelber ${ }^{62}$ ). Nie ma pierwszego ojca (Adama, Noego, czy Sema), pisanego małą czy wielką literą, jest Babel pomieszanie, każde pierwsze imię jest strącone i powielone w nieskończoną ilość przekładów.

U Benjamina, jak zauważa Adam Lipszyc, imię pełni rolę obrazu: obraz jest grudką pojedynczości, która wytrąca się z języka i w języku, a dokładniej: na jego końcu"63, tym samym, zgodnie z tytułem jego monografii o Benjaminie, na końcu języka mamy imię, obraz oraz sprawiedliwość. U Derridy mamy ją na początku. „Imię materialnej istoty pojedynczej" odgrywa rolę realnego, który nie pozwala domknąć się porządkowi symbolicznemu ${ }^{64}$ - tym odwołaniem do Jacques'a Lacana Lipszyc tylko pozornie oddala się od Derridy, gdyż „Realne”, w którym spotykają się obraz, imię własne i sprawiedliwość, to właśnie imię Boga poddane temu, co w L'oreille de l'autre Derrida określa dysheminacją ${ }^{65}$ (disshémination), a więc tekstualną dysseminacją, z tą minimalną abrahamiczną zmianą, czyli dodaną literą h, która sprawia że filiacja, dziedzictwo, ojcostwo jest różnicą i wojną pomiędzy szczepami podzielonymi różnymi językami, a sprawiedliwość jest $a$-venir (tym, co ma nadejść). Bóg i ojciec tych szczepów jest „He war”, a jego teologia jest antagonistyczna.

\section{Bibliografia}

Benjamin W., Anioł historii. Eseje, szkice, fragmenty, wybór i oprac. H. Orłowski, tłum. K. Krzemieniowa, H. Orłowski, J. Sikorski, Poznań 1996.

Benjamin W., Die Aufgabe des Übersetzers, [w:] W. Benjamin, Gesammelte Schriften, t. 5, Frankfurt am Main 1972.

Benjamin W., L'Homme, le langage et la Culture, thum. M. de Gandillac, Paris 1971.

Benjamin W., O języku w ogóle i języku człowieka, thum. A. Lipszyc, „Literatura na Świecie” 2011, nr 5-6, s. 7-26.

Benjamin W., Zadanie tlumacza, thum. A. Lipszyc, „Literatura na Świecie” 2011, nr 5-6, s. 27-41.

Burkert W., Ancient Mystery Cults, Cambridge, Mass. 1987.

Celan P., Szibbolet, „Literatura na Świecie”1998, nr 11-12, s. 328-329.

Certeau M. de, Heterologies, thum. B. Massumi, Minneapolis-London 1986.

Certeau M. de, La fable mystique. XVIe-XVIIe siècle, Paris 1982.

Certeau M. de, The Mystic Fable, vol. 2, trans. M.B. Smith, Chicago-London 2015.

Coward, C., Foshay T. (red.), Derrida and Negative Theology, New-York 1992.

62 W.H. Kelber, The Oral and the Written Gospel, Philadelphia 1983.

${ }^{63}$ A. Lipszyc, Sprawiedliwość na końcu języka. Czytanie Waltera Benjamina, Kraków 2012, s. 523.

${ }^{64}$ Ibidem, przyp. 20.

${ }_{65}$ J. Derrida, L'oreille..., op. cit., s. 137; por. J. Derrida, Dissemination, Paris 1972. 
Day J., From Creation to Babel, Studies in Genesis 1-11, London-New Delhi-New York-Sydney 2013.

Desbois H., Le droit d'auteur en France, Paris 1978.

Derrida and Negative Theology, red. C. Coward, T. Foshay, New York 1992.

Derrida J., Dissemination, Paris 1972.

Derrida J., Edmond Jabès i pytania księgi, tłum. A. Wodnicki, „Literatura na Świecie” 2001, nr 7, s. $137-159$.

Derrida J., Éperons. Les styles de Nietzsche, Chicago 1979.

Derrida J., Fenomenologia i domknięcie się metafizyki, thum. M. Kowalska, [w:] Fenomenologia francuska. Rozpoznania, interpretacje, rozwinięcia, red. J. Migasiński, I. Lorenc, współpr. M. Kowalska, A. Leder, Warszawa 2006, s. 138-159.

Derrida J., L'oreille de l'autre. Textes et débats, Cl. Lévesque, Ch. McDonald (red.), Montreal 1982.

Derrida J., Marginesy filozofii, thum. A. Dziadek, J. Margański, P. Pieniążek, Warszawa 2002.

Derrida J., Mémoires pour Paul de Man, Paris 1988.

Derrida J., Ostrogi. Style Nietzschego, tłum. B. Banasiak, Gdańsk 1997.

Derrida J., Otobiographies. L'enseignement de Nietzsche et la politique du nom propre, Paris 1984.

Derrida J., Parages, Paris 1986.

Derrida J., Points de Suspensions. Entretiens, Paris 1992.

Derrida J., Psyché. Inventions de l'autre, Paris 1987.

Derrida J., Schibboleth. Pour Paul Celan, Paris 1986.

Derrida J., Signéponge, Paris 1988.

Derrida J., Signeponge, tłum. S. Cichowicz, „Literatura na Świecie” 1988, nr 8-9, s. 205-206.

Derrida J., Szibbolet dla Paula Celana, thum. A. Dziadek, Bytom 2000.

Derrida J., Ulysse gramophone - deux mots pour Joyce, Paris 1987.

Derrida J., Wiara i wiedza, thum. P. Mrówczyński, [w:] Religia. Seminarium na Capri prowadzone przez Jacquesa Derridę i Gianniego Vattimo, w którym udział wzięli Maurizio Ferraris, Hans-Georg Gadamer, Aldo Gargani, Eugenio Trias i Vincenzo Vitiello, thum. M. Kowalska i in., Warszawa 1999.

Guibal F. (red.), Altérités, Paris 1986.

Happel O., Der Turmbau zu Babel, „Biblische Zeitschrift” 1903, nr 1, s. 225-244.

Jabès E., Aeli, tłum. A. Wodnicki, Kraków 2006.

Jabès E., Księga pytań, tłum. A. Wodnicki, „Literatura na Świecie” 2001, nr 360, s. 5-132.

Jacobson R., Linguistics and Poetics, Cambridge 1960.

Joyce J., Finnegans Wake, London 1939.

Joyce J., Finneganów Tren, tłum. K. Bartnicki, Kraków 2012.

Katz S., Mysticism and Language, Oxford 1992.

Kelber W.H., The Oral and the Written Gospel, Philadelphia 1983.

La Bible, thum. i red. A. Chouraqui, Paris 1992.

Lipszyc A., Sprawiedliwość na końcu języka. Czytanie Waltera Benjamina, Kraków 2017.

Loy D., Healing Deconstruction: Postmodern Thought in Buddhism and Christianity, Atlanta 1996. Markowski M.P., Efekt inskrypcji. Jacques Derrida i literatura, Bydgoszcz 1997.

Nietzsche F., Radosna wiedza (La gaya scienza), thum. M. Łukasiewicz, Gdańsk 2008.

Pismo Święte Starego i Nowego Testamentu, oprac. Związek Biblistów Polskich z inicjatywy Benedyktynów Tynieckich, Poznań 1998.

Roberts T.T., Contesting Spirit. Nietzsche, Affirmation, Religion, Princeton 1998.

Sadzik P., De Man - Derrida. Pomiędzy konieczna śmiercia a możliwym przeżyciem, „Przegląd Filozoficzno-Literacki” 2015, nr 1, s. 137-155.

Sherman P.M., Babel's Tower Translated. Genesis 11 and Ancient Jewish Interpretation, LeidenBoston 2013. 
Tarnowski K., Pragnienie metafizyczne, Kraków 2017.

Taylor M.C., Erring. A Postmodern A/theology, Chicago-London 1987.

Vries H. de, Anti-Babel. The „Mystical Postulate” in Benjamin, de Certeau and Derrida, „MLN” 1992, vol. 107, no. 3, s. 441-477. 